\title{
Article \\ Spatial Variability of Soil Properties and Its Effect on Maize Yields within Field-A Case Study in Hungary
}

\author{
Anikó Nyéki ${ }^{1, * \mathbb{C}}$, Bálint Daróczy ${ }^{2,3}$, Csaba Kerepesi ${ }^{3,4}$, Miklós Neményi ${ }^{1}$ and Attila József Kovács ${ }^{1}$ \\ 1 Biosystems and Food Engineering, Széchenyi István University, 9200 Mosonmagyaróvár, Hungary; \\ nemenyi.miklos@sze.hu (M.N.); kovacs.attila@sze.hu (A.J.K.) \\ 2 Mathematical Engineering (INMA), Université Catholique de Louvain, B-1348 Louvain-la-Neuve, Belgium; \\ daroczyb@ilab.sztaki.hu \\ 3 Institute for Computer Science and Control, Eötvös Lóránd Research Network, 13-17. Kende Str., \\ 1111 Budapest, Hungary; ckerepesi@bwh.harvard.edu \\ 4 Gladyshev Lab, Harvard Medical School, Avenue Louis Parker 77, Boston, MA 02115, USA \\ * Correspondence: nyeki.aniko@sze.hu
}

check for updates

Citation: Nyéki, A.; Daróczy, B.; Kerepesi, C.; Neményi, M.; Kovács, A.J. Spatial Variability of Soil Properties and Its Effect on Maize Yields within Field-A Case Study in Hungary. Agronomy 2022, 12, 395. https://doi.org/10.3390/ agronomy12020395

Academic Editor: Xiaobing Liu

Received: 5 January 2022

Accepted: 3 February 2022

Published: 4 February 2022

Publisher's Note: MDPI stays neutral with regard to jurisdictional claims in published maps and institutional affiliations.

Copyright: (C) 2022 by the authors. Licensee MDPI, Basel, Switzerland. This article is an open access article distributed under the terms and conditions of the Creative Commons Attribution (CC BY) license (https:// creativecommons.org/licenses/by/ $4.0 /)$.

\begin{abstract}
To better understand the potential of soils, understanding how soil properties vary over time and in-field is essential to optimize the cultivation and site-specific technologies in crop production. This article aimed at determining the within-field mapping of soil chemical and physical properties, vegetation index, and yield of maize in 2002, 2006, 2010, 2013, and 2017, respectively. The objectives of this five-year field study were: (i) to assess the spatial and temporal variability of attributes related to the maize yield; and (ii) to analyse the temporal stability of management zones. The experiment was carried out in a 15.3 ha research field in Hungary. The soil measurements included sand, silt, clay content $(\%), \mathrm{pH}$, phosphorous $\left(\mathrm{P}_{2} \mathrm{O}_{5}\right)$, potassium $\left(\mathrm{K}_{2} \mathrm{O}\right)$, and zinc $(\mathrm{Zn})$ in the topsoil $(30 \mathrm{~cm})$. The apparent soil electrical conductivity was measured in two layers $(0-30 \mathrm{~cm}$ and $30-90 \mathrm{~cm}, \mathrm{mS} / \mathrm{m})$ in 2010, in 2013, and in 2017. The soil properties and maize yields were evaluated in 62 management zones, covering the whole research area. The properties were characterized as the spatial-temporal variability of these parameters and crop yields. Classic statistics and geostatistics were used to analyze the results. The maize yields were significantly positively correlated $(r=0.62-0.73)$ with the apparent electrical conductivity (Veris_N3, Veris_N4) in 2013 and 2017, and with clay content $(\mathrm{r}=0.56-0.81)$ in 2002, 2013, and 2017.
\end{abstract}

Keywords: soil chemical and physical properties; spatial and temporal variability; maize yield maps; management zones; precision agriculture

\section{Introduction}

For precise determination of the best soil management practices and amendments to increase crop quantity and quality while being environmentally sustainable, it is necessary to understand the spatial and temporal variability in soil properties and yield [1-3]. Varying field conditions are a major source of uncertainty in precision site-specific crop production [4]. It is essential to know whether the spatial distribution of crop parameters is stable over time before applying site-specific management [5].

A significant amount of spatial variability and a significant amount of time variability was observed for the maize yield within field [6], and among years, there was marked variability in total growing season precipitation, which likely led to the variability in grain yields. Variability occurs on different scales in both spatial and temporal domains. The level of climate variable can be relatively homogeneous within a cultivation site [7], while physical and chemical characteristics of soil can change on a submeter-scale [8]. Plant growth is affected by the environmental factors that surround the plant. Maize is highly sensitive to environmental conditions, especially to abiotic factors such as rainfall, available soil moisture, air and soil temperature, soil type, etc. [9]. The variability of the 
physical, chemical, and biological properties of the soil is the major factor for the diversity in crop production [10]. The grain yield maps, NDVI, and soil properties presented do not support the notion that the variables are spatially associated [11]. Soil properties that were significantly different between management zones ultimately affected the available water and, therefore, the nutrient uptake within each zone. In general, the trends observed for the soil properties followed the productivity potential of the management zones [12]. Spatial and temporal variability of crop performance must be managed by crop management over time and space [13]. The most relevant factors influencing crop growth, in a dry environment such as the study site, are mainly the soil physical properties which control water-holding capacity, such as texture, bulk density, and organic matter [13]. The extent of change in the physical properties of agricultural soils during a growing season is strongly affected by soil management [14]. The amount of water influences and generates more frequently extreme effects in different forms, according to soil texture and the root system of cereals [15]. In individual years, maize yield varied according to the soil water content. Soane [16] found a positive maize response to compaction during the dry years and a negative response in the wetter seasons. In the case of silt loam soils, maize yield reductions were observed in wet years (because of poor drainage), based on a standard meteorology year, but in dry years, yield was increased [17]. Franke et al. [18] found 4.9 and $4.4 \mathrm{t} /$ ha maize yield, with an average $4.65 \mathrm{t} / \mathrm{ha}$, in loam soil with $25 \%$ clay content (2002 and 2003: rainy years), while the dry season in 2004 produced $3.9 \mathrm{t} / \mathrm{ha}$ maize yield. In contrast to this, a fertilizer response was absent. High spatial Zn variability with moderate spatial dependence was shown by Shukla et al. [19]. The major objective of this study was therefore to determine the spatial soil variability within field of selected physical and chemical properties including the content of textural fractions, $\mathrm{pH}$, phosphorous $\left(\mathrm{P}_{2} \mathrm{O}_{5}\right)$, potassium $\left(\mathrm{K}_{2} \mathrm{O}\right)$, and zinc $(\mathrm{Zn})$ in the topsoil $(30 \mathrm{~cm})$, electrical conductivity in two layers, and Normalized Difference Vegetation Index (NDVI) in a long-term experiment. The specific objectives were to (i) identify soil properties that control maize yields in different weather conditions during a growing season, and (ii) mapping soil variables and crop yields across the field using management zones. For this purpose, the spatial variability of crop production of maize and soil parameters were evaluated and the correlation between these was analyzed.

\section{Materials and Methods}

\subsection{Study Area}

The experimental field (Figure 1) is situated in Mosonmagyaróvár, Hungary [ $47^{\circ} 54^{\prime} 20.00^{\prime \prime} \mathrm{N}$, $17^{\circ} 15^{\prime} 10.00^{\prime \prime}$ E] belonging to Széchenyi István University. The research field size is 15.3 ha, including 62 management zones. The soil texture of the agricultural field is an alluvial plain of the Leitha River with Fluvisoil [20], which, according to the USDA [21], indicate the soil types of loam, silty loam, and sandy loam (Figure 2), on which precision agriculture technologies have been utilized since 2001 . More than $60 \%$ of these soil types are used in this area (region). The crop field has a little slope with an elevation range of 133-138 m. Crop rotation includes mostly cereals: winter wheat, spring barley, maize, and soybean. After harvesting cereals, the conventional tillage system consists of stubble tillage $(\sim 15 \mathrm{~cm})$, followed by mouldboard ploughing $(\sim 20 \mathrm{~cm})$, disking, and tooth harrowing to prepare the seedbeds for winter crops. In the fall, spring cereals are ploughed, and tillage systems are prepared [22].

\subsection{Soil Sampling, Site-Specific Measurements and Remotely Sensed Crop Data}

Soil samples were collected before maize sowing from each management zone to be subjected to standard methods of laboratory analysis. Clay, silt, sand content (\%), $\mathrm{pH}$, phosphorous $\left(\mathrm{P}_{2} \mathrm{O}_{5}\right)$, potassium $\left(\mathrm{K}_{2} \mathrm{O}\right)$, and zinc $(\mathrm{Zn})$ content were measured. Twenty to twenty-five soil measurements were taken across the management units in the topsoil (upper $30 \mathrm{~cm}$ ). Assuming that all 15.3 ha of the experimental field is managed by 62 zones, one measurement point corresponds to a management unit of $\sim 2500 \mathrm{~m}^{2}$. From 2011, an AgLeader InCommandTM 1200 (AgLeader Technology Inc., Ames, IA, USA) yield 
mapping system was used, which was mounted on a CLAAS Medion 340 grain harvester. A Veris Soil EC-3100 instrument (Salina, KS, USA) was used to measure soil electrical conductivity (ECa) in 2010, 2013, and 2017. The soil electrical conductivity (ECa) was measured in shallow soil (less than $0.3 \mathrm{~m}$ below ground level) and deep soil (between 0.3-0.9 m below ground level). A self-developed system [23] was used to measure soil draft on the go. Site-specific penetrometer measurements were performed using a 3T system penetrometer [24]. The yield, electrical conductivity, and soil draft of each management zone were averaged. Site-specific measurements were conducted before maize vegetation seasons.

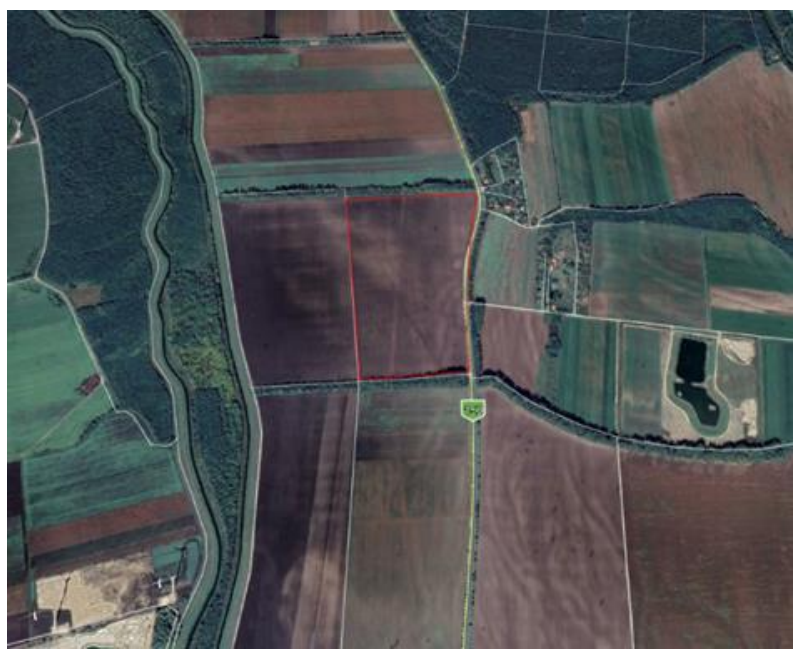

Figure 1. The experimental field (outlined in red) in Hungary.

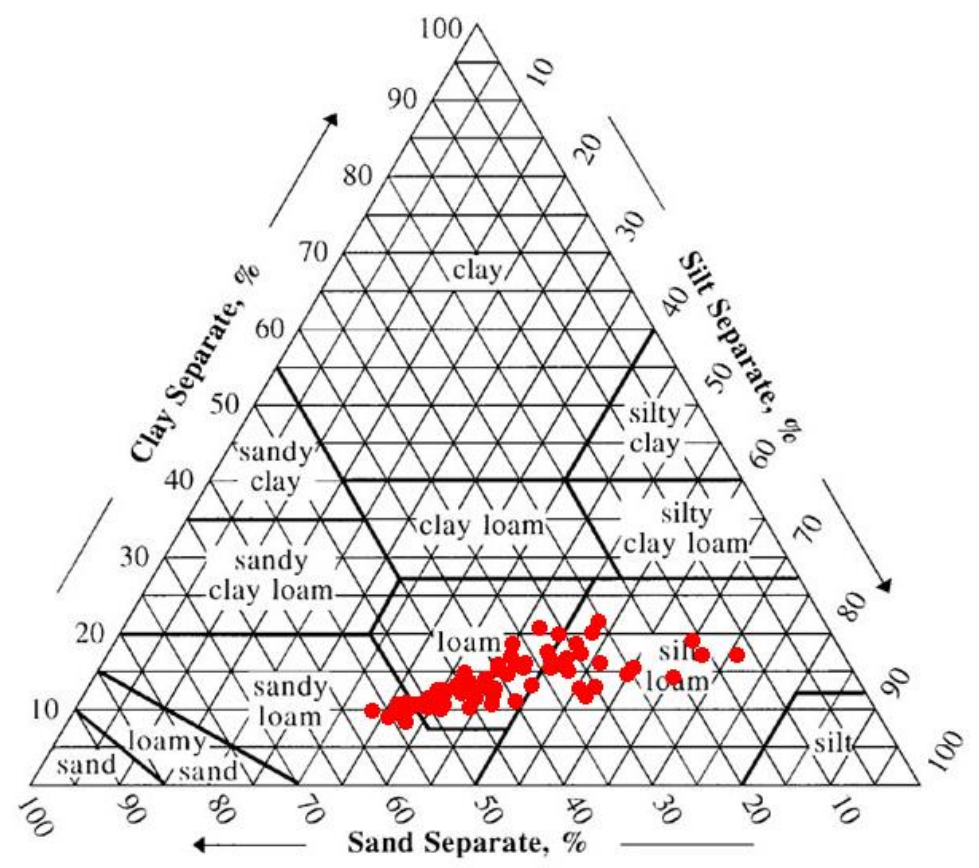

Figure 2. The soil texture scattering of 62 management zones in field.

In order to estimate crop characteristics, several parameters were determined. NDVI values were evaluated from satellite data by Landsat on 26 July 2006; 5 July 2010; 29 July 2013, and 9 August 2017. The remotely sensed images were collected under high quality (maximum cloud coverage was under 5\%) atmospheric conditions during the maize flowering period. 


\subsection{Weather, Meteorological Data}

The sum of precipitation, average temperature, average relative precipitation, evapotranspiration, and aridity index (evapotranspiration/precipitation) were collected and analysed for the years 2002, 2006, 2010, 2013, and 2017 in the study site from April to October during the vegetation season of the maize plant. There was a distance of $1.78 \mathrm{~km}$ between the observed field and the university's weather station. Table 1 illustrates the major meteorological parameters in growing seasons. The growing season of 2002 (April-October) was very dry with $358 \mathrm{~mm}$ of rain. The year of 2010 was extremely wet, but rainfall was lower than average in 2017.

Table 1. Summarized meteorological parameters in the examined years.

\begin{tabular}{cccccc}
\hline & $\mathbf{2 0 0 2}$ & $\mathbf{2 0 0 6}$ & $\mathbf{2 0 1 0}$ & $\mathbf{2 0 1 3}$ & $\mathbf{2 0 1 7}$ \\
\hline Sum. precipitation during & 353.8 & 405.4 & 597.9 & 398.4 & 332.7 \\
vegetation period (IV-X) & & 811 & 690 & 845 & 951 \\
evapotranspiration (mm) & 2.6 & 2.2 & 1.2 & 2.1 & 2.9 \\
aridity index & 25.9 & 90 & 150.3 & 125.9 & 26.7 \\
precipitation in May (mm) & 40.2 & 59.1 & 100 & 42.2 & 40 \\
precipitation in June (mm) & & &
\end{tabular}

\subsection{Dataset Definition and Statistical Analysis}

The dataset was compiled from data from the abovementioned sources. The database table consisted of $310(n=62 \times 5)$ rows for each treatment unit and year, and also 48 columns for each parameter and maize yield. In summary, four types of parameters were used: (i) analysis of soil parameters over the five years: $\mathrm{pH}, \mathrm{P}_{2} \mathrm{O}_{5}, \mathrm{~K}_{2} \mathrm{O}$, and $\mathrm{Zn}$; measured in three years: $E C_{a}$ in two layers, Veris N3, and N4; measured in one year: Cone Index ( $\mathrm{MPa}), \mathrm{pH}$ (water), draught force $(\mathrm{kN})$, (ii) crop parameters (NDVI, measured in four years), (iii) non-changing soil variables (clay content (\%), relative elevation (m) evaluated in one year (2010) but used in all years). (iv) Of the 35 meteorological features observed, the following five values were measured in each month from April to October during the growing season of maize: sum of precipitation, average temperature, average relative precipitation, vaporization, evapotranspiration, and aridity index [22].

The variables of soil, vegetation indexes, and maize yield were analysed using a geostatistical analysis assuming that each variable had a spatial structure. We analysed the soil properties, the vegetation index, and crop yields using basic statistical parameters, namely, mean, standard deviation, coefficient of variation (CV), maximum, and minimum values.

\section{Results and Discussion}

\subsection{Basic Statistics-Spatial Variability of Maize Yields, Soil Properties, Electrical Conductivity, and Vegetation Indices}

Descriptive statistics for the soil physical and chemical properties (including electrical conductivity, cone index, and draught force) and crop variables of the cultivated field are given in Table 2. The maize yield ranged between 2.46 and 15.05 tonnes per hectare, with an average of $9.39 \mathrm{t} / \mathrm{ha}$. The high variability with the same crop management under similar weather conditions in field, suggest that the variability of maize yields can be explained by other factors, including the soil properties of management zones. Variability in maize yield $(\mathrm{CVs}<17 \%)$ was smaller than variability in important soil properties. Table 2 shows that several variables showed a high level of variability with coefficients of variation above $30 \%$. Coefficients of variation indicate that the largest variations were found in the case of the $\mathrm{K}_{2} \mathrm{O}\left(\mathrm{mg} / \mathrm{kg}\right.$ ), Veris (N3), and NDVI. Moreover, $\mathrm{K}_{2} \mathrm{O}$ content (22.6 to $518 \mathrm{mg} / \mathrm{kg}$ ) and $\mathrm{P}_{2} \mathrm{O}_{5}$ content (123 to $415 \mathrm{mg} / \mathrm{kg}$ ) values showed remarkable variations among the treatment units in the field. The variation coefficients of clay content and draught force were almost the same (23\%). The mean content of electrical conductivity (Veris) in the topsoil (N3) was slightly lower $(13.37 \mathrm{mS} / \mathrm{m})$ than in the subsoil (N4), $17.06 \mathrm{mS} / \mathrm{m}$. The pattern of variability 
of Veris N3 and N4 was the same because the rise of values depends only on the water content of soil and the rainfall, as well. This was the case during the five sampling periods.

Table 2. Descriptive statistics for the soil properties, on-line measurements, and crop parameters in examined years. Min, minimum; Max, maximum; Mean, mean (average); SD, standard deviation; $\mathrm{CV}$ coefficient of variation (the ratio of the standard deviation to the mean).

\begin{tabular}{|c|c|c|c|c|c|}
\hline Variable & 2002 & 2006 & $\begin{array}{c}\text { Mean (STD) } \\
\text { Min-Max } \\
\text { CV } \\
2010\end{array}$ & 2013 & 2017 \\
\hline \multirow[t]{3}{*}{ Maize_yield_t/ha } & $6.12(1.62)$ & $11.48(0.41)$ & $9.89(0.86)$ & $11.52(1.91)$ & $7.79(2.41)$ \\
\hline & $2.46-9.43$ & $10.44-12.36$ & 7.63-11.97 & $7.33-15.05$ & $3.11-13.18$ \\
\hline & 0.27 & 0.04 & 0.09 & 0.17 & 0.31 \\
\hline \multirow[t]{3}{*}{ pH_H ${ }_{2} \mathrm{O}$} & $7.76(0.05)$ & - & - & - & - \\
\hline & $7.62-7.93$ & - & - & - & - \\
\hline & 0.01 & - & - & - & - \\
\hline \multirow[t]{3}{*}{ pH_KCl } & $7.3(0.07)$ & $7.33(0.1)$ & $7.36(0.09)$ & $7.53(0.17)$ & $7.46(0.09)$ \\
\hline & $7.15-7.42$ & $7.11-7.51$ & $7.09-7.52$ & $7.23-7.83$ & $7.24-7.62$ \\
\hline & 0.01 & 0.01 & 0.01 & 0.02 & 0.01 \\
\hline \multirow[t]{3}{*}{$\mathrm{P}_{2} \mathrm{O}_{5} \_\mathrm{mg} / \mathrm{kg}$} & $271.16(67.56)$ & $244.05(42.86)$ & $265.14(46.83)$ & $214.43(39.15)$ & $193.65(36.8)$ \\
\hline & $123-388$ & $181-415$ & $180-376$ & $151-347$ & 131-308 \\
\hline & 0.25 & 0.18 & 0.18 & 0.18 & 0.19 \\
\hline \multirow[t]{3}{*}{$\mathrm{K}_{2} \mathrm{O} \_\mathrm{mg} / \mathrm{kg}$} & $90.83(15.91)$ & $79.03(13.66)$ & $194.21(41.46)$ & $318.89(53.08)$ & $77.72(21.83)$ \\
\hline & 65-162 & 58-135 & $121-317$ & $226-518$ & 22.6-158 \\
\hline & 0.18 & 0.17 & 0.21 & 0.17 & 0.28 \\
\hline \multirow[t]{3}{*}{ Zn_mg/kg } & $3.61(0.43)$ & $3.06(0.37)$ & $2.24(0.41)$ & $3(0.51)$ & $2.67(0.51)$ \\
\hline & $2.7-4.7$ & $2.2-4$ & $1.21-3.14$ & $2.17-4.43$ & $1.58-3.88$ \\
\hline & 0.12 & 0.12 & 0.18 & 0.17 & 0.19 \\
\hline \multirow[t]{3}{*}{ Clay_content_\% } & $13.25(3.14)$ & $13.25(3.14)$ & $13.25(3.14)$ & $13.25(3.14)$ & $13.25(3.14)$ \\
\hline & $7.9-21$ & $7.9-21$ & $7.9-21$ & $7.9-21$ & $7.9-21$ \\
\hline & 0.24 & 0.24 & 0.24 & 0.24 & 0.24 \\
\hline \multirow[t]{3}{*}{ Draught_force_kN } & $3.17(0.86)$ & - & - & - & - \\
\hline & $1.52-6.12$ & - & - & - & - \\
\hline & 0.27 & - & - & - & - \\
\hline \multirow[t]{3}{*}{$\begin{array}{c}\text { Relative } \\
\text { elevation_m }\end{array}$} & $122.72(0.35)$ & $122.72(0.35)$ & $122.72(0.35)$ & $122.72(0.35)$ & $122.72(0.35)$ \\
\hline & 121.96-123.6 & 121.96-123.6 & 121.96-123.6 & 121.96-123.6 & $121.96-123.6$ \\
\hline & 0 & 0 & 0 & 0 & 0 \\
\hline \multirow[t]{3}{*}{ NDVI } & - & $0.66(0.03)$ & $0.29(0.05)$ & $0.47(0.02)$ & $0.4(0.02)$ \\
\hline & - & $0.57-0.69$ & $0.2-0.42$ & $0.4-0.49$ & $0.37-0.45$ \\
\hline & - & 0.04 & 0.16 & 0.05 & 0.05 \\
\hline \multirow[t]{3}{*}{ Veris_N3 } & - & - & $18(4.84)$ & $8.18(1.51)$ & $13.58(7.18)$ \\
\hline & - & - & $9.68-30.55$ & $5.51-10.96$ & $5.5-39.12$ \\
\hline & - & - & 0.27 & 0.18 & 0.53 \\
\hline \multirow[t]{3}{*}{ Veris_N3 } & - & - & $17.57(5.1)$ & $11.76(2.74)$ & $21.54(7.67)$ \\
\hline & - & - & $8.89-30.94$ & $6.94-18.47$ & $8.33-37.83$ \\
\hline & - & - & 0.29 & 0.23 & 0.36 \\
\hline \multirow[t]{3}{*}{ Cone_Index_Mpa } & - & - & - & $44.68(7.61)$ & - \\
\hline & - & - & - & $22.47-58.74$ & - \\
\hline & - & - & - & 0.17 & - \\
\hline
\end{tabular}

\subsection{Spatial Distribution of Maize Yields and Site-Specific Variables}

The spatial distribution of soil and crop parameters are presented in Figure 3. The spatial structure of $\mathrm{K}_{2} \mathrm{O}(\mathrm{mg} / \mathrm{kg}), \mathrm{P}_{2} \mathrm{O}(\mathrm{mg} / \mathrm{kg})$ was nearly the same during both years, similarly, Veris_N3 and Veris_N4 were nearly the same during each year, as well as spatial distribution. Various external factors influenced the variability of these properties, including irrigation and site-specific fertilization, but the field was rainfed, and there were homogenous chemical fertilizer applications. The difference in chemical parameters, such 
as $\mathrm{Zn}(\mathrm{mg} / \mathrm{kg})$ content, during the years indicated spatial as well as temporal variability. Due to different management practises, such as microelement fertilizer adopted for different crops, the divergent nutrient uptake by different crops was expected. In comparison to the other micronutrients, $\mathrm{Zn}$ variability in soil is largely determined by the different sources of variation [25]. Based on the maps of soil $\mathrm{pH}(\mathrm{KCl}), \mathrm{pH}$ ranged from 7.09 to 7.83 , indicating that most soils in the management zones were neutral during the experiments.
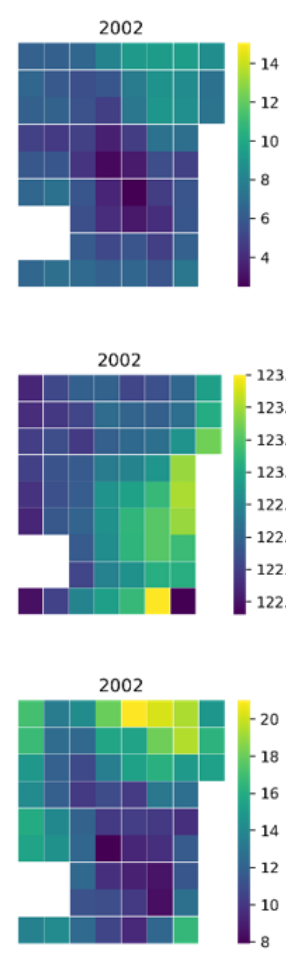

2002

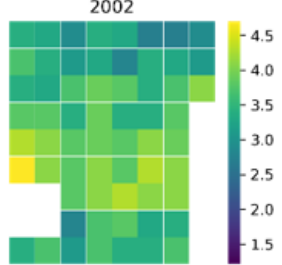

2002

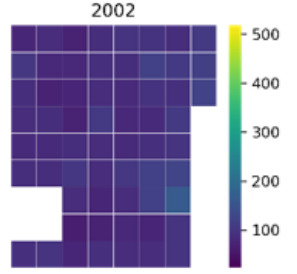

2002

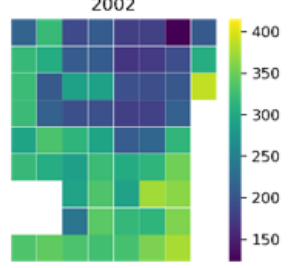

Maize_yield_t/ha

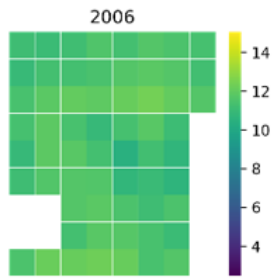

2006
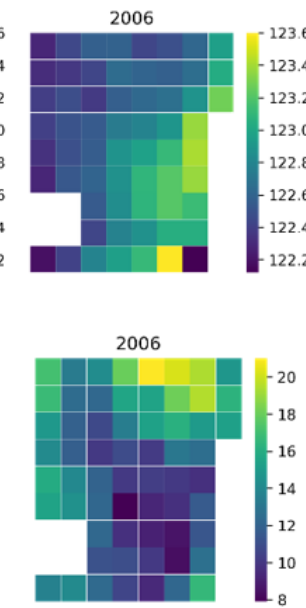

2006

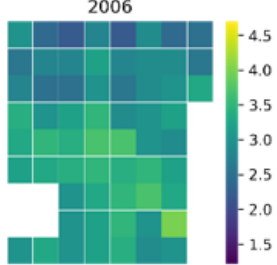

2006

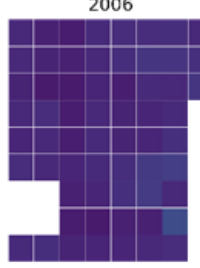

2006

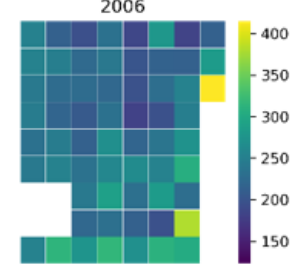

2010

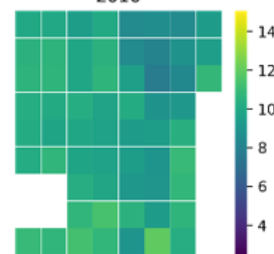

Relative elevation $\mathrm{m}$

2010

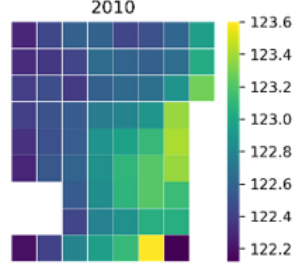

Clay_content_\%

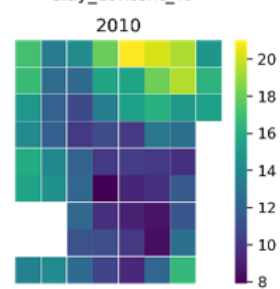

Zn_mg/kg

2010

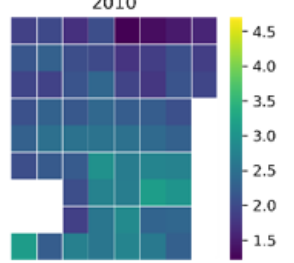

K2O_mg $/ \mathrm{kg}$

2010

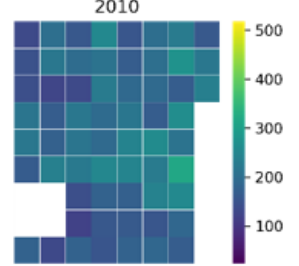

P2O5_mg/kg

2010

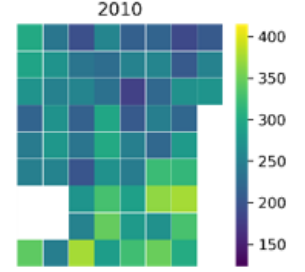

2013

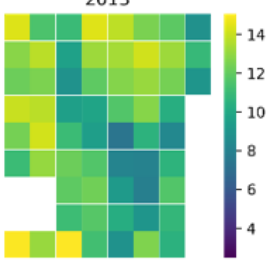

2013

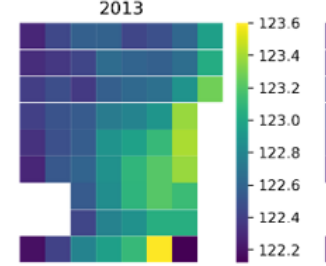

2013

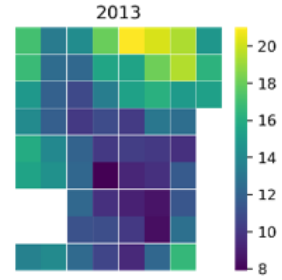

2013

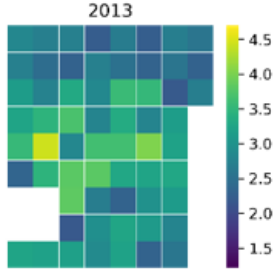

2013

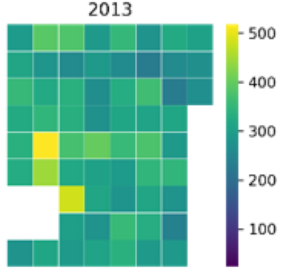

2013

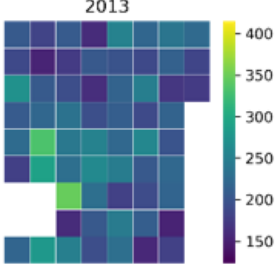

2017

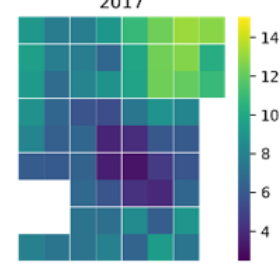

2017
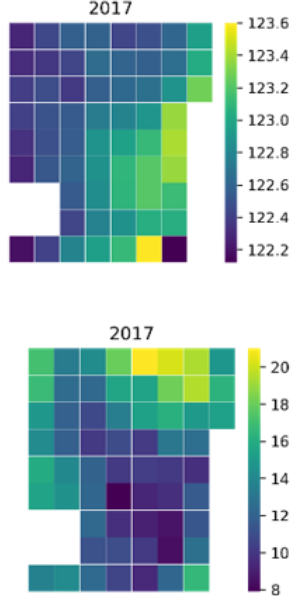

2017

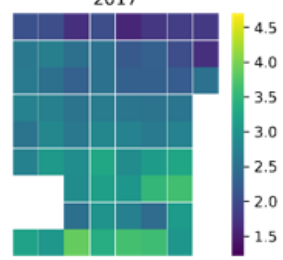

2017

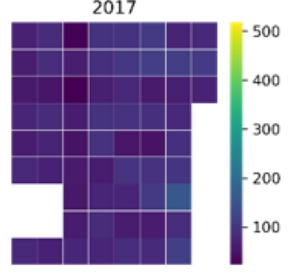

2017

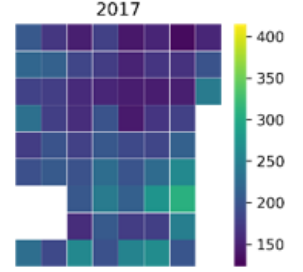

Figure 3. Cont. 


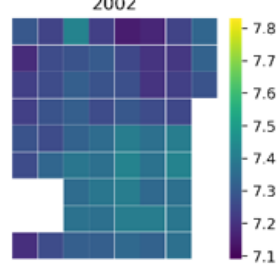

2006

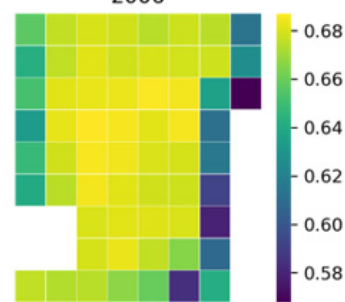

VERIS_N3

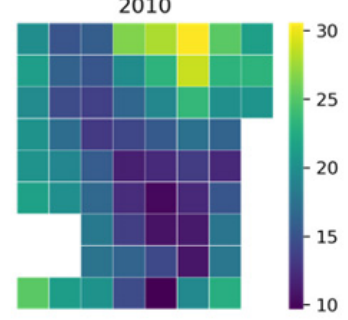

$\mathrm{PH}+\mathrm{H} 2 \mathrm{O}$

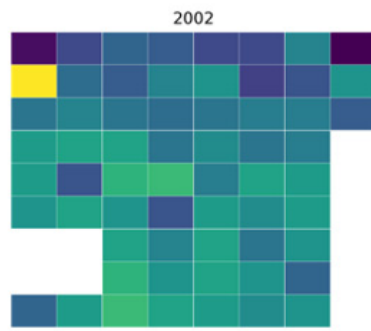

2006

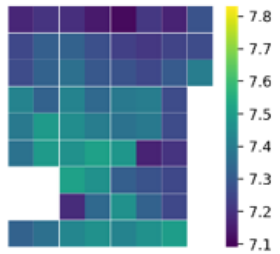

$\mathrm{pH} \_\mathrm{KCl}$

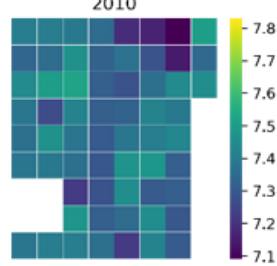

NDVI

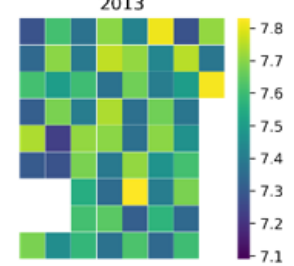

2017
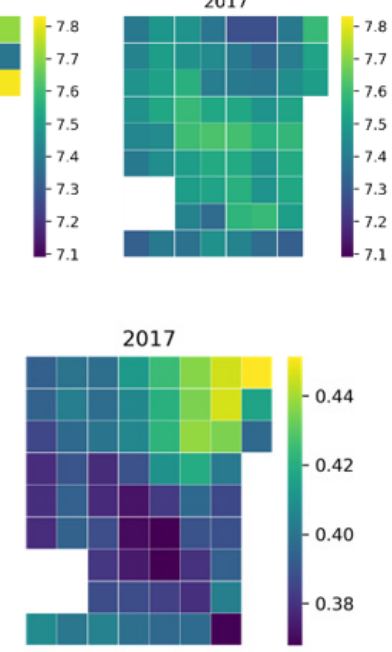

VERIS_N4

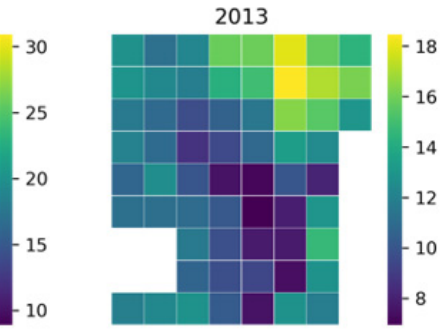

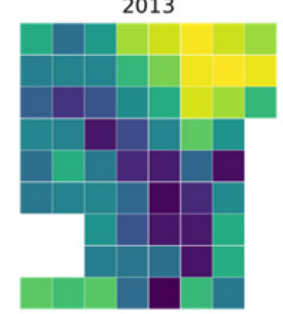

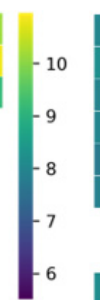

2010

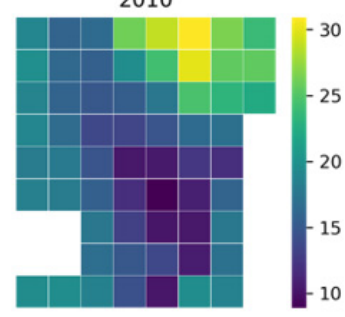

Draught force_kN

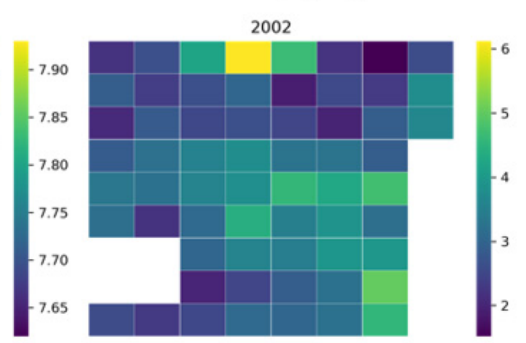

Figure 3. Spatial distribution of the variables in the field with management zones.

Spatial distribution of Veris N3, Veris N4, and clay content that mostly correlated with the crop yield, show general similarity in the distributions with maize yields. In the middle part of the field, the relatively low yields were accompanied by relatively low content of clay content, Veris N3, and N4 values. This part of the field is sandy loam (with higher sand and silt content). On the contrary, high $\mathrm{Zn}$ and $\mathrm{pH}$ content were found in these management zones in most cases. It appears that within a given field, there can be spatial differences in several soil parameters and maize yields [26].

\subsection{Relationship of All Variables and Maize Yields}

Correlation analysis was performed to determine the degree to which spatial variability in maize yields can be explained by the site-specific parameters, see Figures 4 and 5 . The detailed histograms can be found in Appendix A Figure A1. We found that $\mathrm{Zn}, \mathrm{pH}(\mathrm{KCl})$, $\mathrm{pH}(\mathrm{H} 2 \mathrm{O})$, and $\mathrm{P}_{2} \mathrm{O}_{5}$ parameters had normal distributions for all years in the study. There are several significant correlations $(p$ value $<0.01)$ which we are discussing in detail. There was significant positive correlation between maize yield and potassium content (0.41). Potassium absorption in the maize vegetative stage occurs at the beginning of floral differentiation. The normalized difference vegetation index showed the stage and vigour of the crops, so that its extent (0.45) influenced the maize yield potential. When analysing 
the relative elevation $(\mathrm{m})$, which was correlated with the clay content $(-0.51)$, the field elevation did not influence the yields in this experiment.

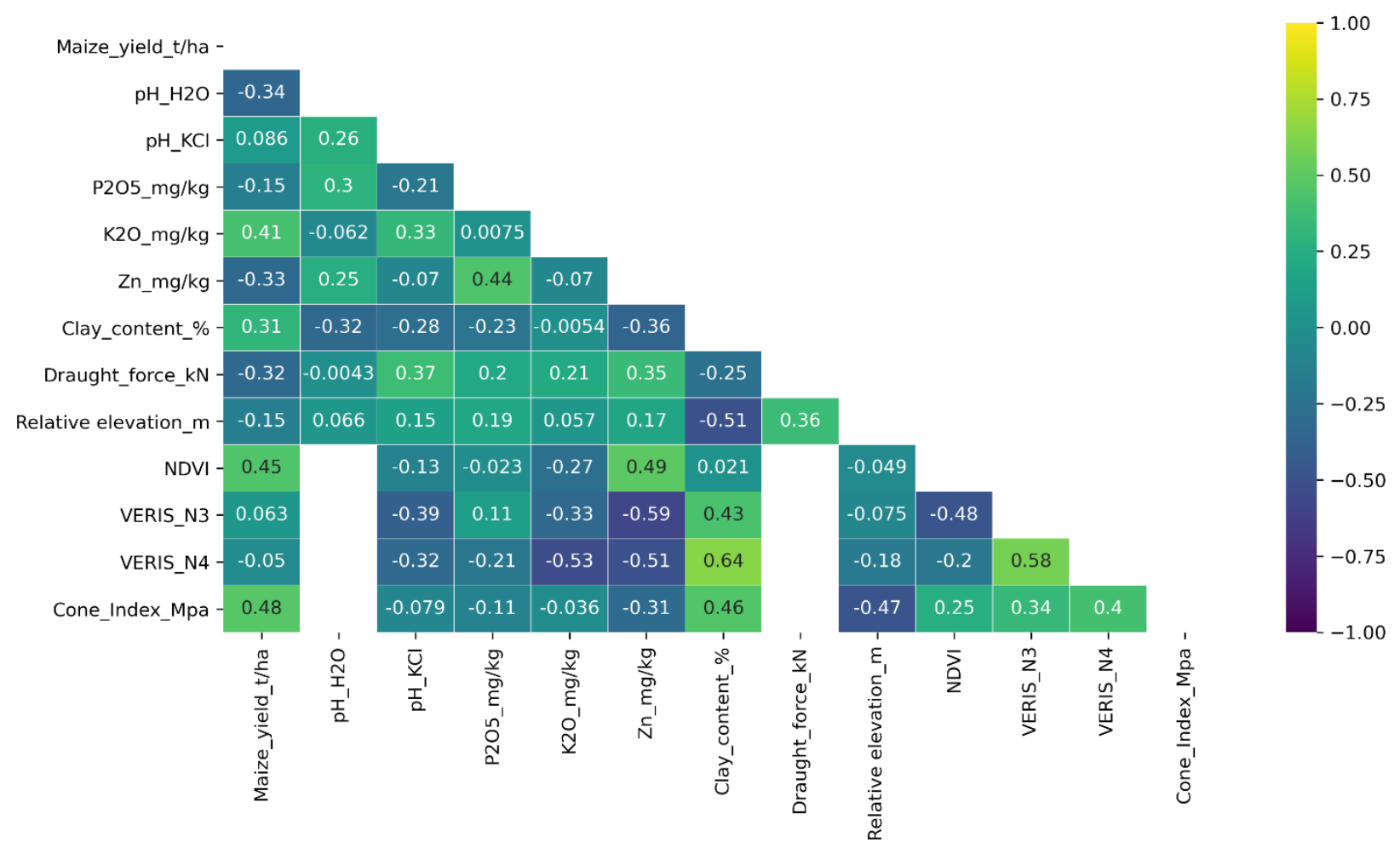

Figure 4. Pearson correlations (r) between the maize yields, soil properties, and vegetation indices in all years.

\begin{tabular}{|c|c|c|c|c|c|c|}
\hline pH_H2O- & -0.34 & & & & & -1.00 \\
\hline pH_KCl- & -0.61 & 0.26 & 0.24 & -0.06 & -0.47 & -0.75 \\
\hline P2O5_mg/kg - & -0.38 & -0 & 0.43 & 0.12 & -0.43 & \\
\hline $\mathrm{K} 2 \mathrm{O} \_\mathrm{mg} / \mathrm{kg}$ & 0.15 & -0.26 & -0.1 & -0.02 & 0.09 & \\
\hline $\mathrm{Zn} \_\mathrm{mg} / \mathrm{kg}$ - & -0.51 & -0.12 & 0.37 & -0.08 & -0.6 & -0.25 \\
\hline Clay_content_\% - & 0.81 & 0.12 & -0.25 & 0.56 & 0.77 & \\
\hline Draught_force_kN - & -0.32 & & & & & 0.00 \\
\hline Relative elevation_m - & -0.27 & -0.19 & -0.05 & -0.52 & -0.2 & -0.25 \\
\hline NDVI - & & 0.28 & 0.72 & 0.18 & 0.84 & \\
\hline VERIS_N3 - & & & -0.15 & 0.64 & 0.62 & \\
\hline VERIS_N4 - & & & -0.27 & 0.62 & 0.73 & -0.75 \\
\hline Cone_Index_Mpa - & & & & 0.48 & & \\
\hline & 2002 & 2006 & 2010 & 2013 & 2017 & \\
\hline
\end{tabular}

Figure 5. Pearson correlations (r) of maize yield in the examined years.

A low negative correlation was obtained between Veris_N3 (-0.39), Veris_N4 (-0.32), and $\mathrm{pH}$ in the studied years, but Veris was strongly negatively correlated with chemical soil parameters such as $\mathrm{Zn}$ content $(-0.51-0.59)$ and potassium $(-0.33-0.53)$. Zn content had a significant effect on maize yields [27]. In the examined five years, precipitation in May was identified as the most important influencing factor for maize yields in this field [22]. 
The $\mathrm{pH}$ of the soil, the clay content, the electrical conductivity of the upper layer, and the normalized difference vegetation index ranked among the top five factors.

Parameters were examined in each year separately (Figure 5). In 2001 and 2015, the yield was significantly and positively correlated with the soil electrical conductivity (Veris N3, N4) in the upper and lower layers $(0.62-0.73)$, too. A positive relationship was observed between maize yields and NDVI (from 0.28-0.84) in each year. The soil clay content, which was strongly correlated with Veris N3 and N4 (Figure 4), in 2002, 2013, and 2017 showed positive correlation with maize yields, but in 2010, there was no significant relation. However, the physical texture did not change within the years; this anomaly can be interpreted by soil moisture content (more precipitation in vegetation season) resulting in the mechanical behaviour of soil. Understanding seed germination variability in spring and its impact on crop yield may be important. Water content in the soil influenced the spatial patterns of thermal properties (clay content) in a field, which in turn influenced tillage and water management [28]. Irrespective of the study year, the relative elevation of the field was negatively correlated with the maize yields. Among soil properties, the soil potassium content showed very weak and mostly negative correlation with cereal yields, while relations between phosphorus and yield changed year by year. Soil properties in site-specific management can affect the nutrient uptake and productivity potential of the management zones [12]. The variables of soil physical structure, such as draught force and cone index, showed opposite results. In 2013, between the cone index and maize yield we diagnosed a strong positive correlation, but in 2002, between the draught force and yield, we detected a negative relation. The abovementioned results $[15,16,18]$ discuss the change of maize yields and soil resistance resulting in soil textures and soil water content in different seasons.

Figure 6 presents the distribution of maize yields in management zones over five years. In different years, low yield values appeared near the middle of the field according to the maps. In this part, clay levels were lower than in other treatment units. The positive and significant correlations in the cereal yields and similar spatial distribution of the crop yields were discussed [29]. Maize yield was influenced by site properties, tillage, and nitrogen treatments [9]. This paper highlighted the rainfall amounts in the critical period (May). May precipitation was identified as the most important influencing factor; hence, comparing the different meteorological parameters during the different vegetation seasons may be useful. A previous study [14] also revealed that the observed changes in spatial yield pattern over the years demonstrated the substantial influence of meteorological patterns, especially under rainfed and irrigation system [30] conditions. It is important to focus on multi-field and multi-year comparisons of time-specific and static management zones and their impact on crop yields [31].

2002

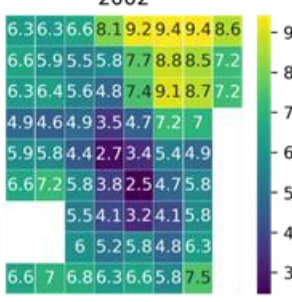

2006

\begin{tabular}{|l|l|l|l|l|l|l|l|l|}
\hline 11 & 11 & 11 & 12 & 11 & 12 & 12 & 11 & -12.25 \\
\hline 11 & 11 & 11 & 11 & 12 & 12 & 12 & 11 & -12.00 \\
\hline 11 & 12 & 12 & 12 & 12 & 12 & 12 & 12 & -11.75 \\
\hline 11 & 12 & 11 & 11 & 11 & 12 & 11 & & -11.50 \\
\hline 11 & 12 & 12 & 11 & 10 & 11 & 11 & & -11.25 \\
\hline 11 & 12 & 12 & 12 & 11 & 11 & 11 & & -11.00 \\
\hline & 12 & 12 & 11 & 11 & 12 & & -12 \\
& & 11 & 12 & 12 & 11 & 11 & -10.75 \\
\hline 11 & 12 & 12 & 12 & 12 & 11 & 12 & -10.50 \\
\hline
\end{tabular}

2010

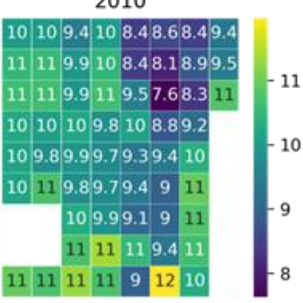

2013

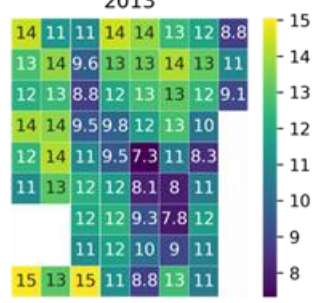

2017

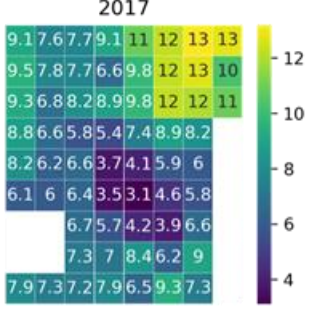

Figure 6. Maize yield distribution of the field using the same scale of each year (relative yield distribution in the management zones, $\mathrm{t} / \mathrm{ha}$ ).

\section{Conclusions}

This study provides evidence of how maize yields are correlated and spatial-temporally dependent on selected soil physical and chemical properties. The article focused on the spatial patterns of the soil and crop variables and yields in the context of precision crop production management. The maize yields presented spatial and temporal variability within the field. This was explained by the spatial distribution of potassium content, elec- 
trical conductivity values, and clay content that influence soil fertility and are essential to the development, growth, and productivity of field crops. In general, the correlation coefficients also showed soil textural properties (clay content) and apparent soil electrical conductivity were highly correlated to the maize yields during the five years. The distribution maps with management zones showed positional similarities with each other. Therefore, these maps can be used for irrigation and fertilizer application management, too. The highest positive and significant correlations with maize yields in our study were obtained for vegetation index (0.84) and soil electrical conductivity (0.73) in 2017. Overall, the temporal-spatial results showed that the distribution maps and statistical analysis are one of the tools to determine interactions between soil, crop, and meteorological variables of crop yields within fields, in management zones. Moreover, it may improve productivity on sub-field (treatment units) with low soil quality and fertility.

The mentioned results are related to the fact that crop (maize) yields under field conditions and within field, in Hungary, are a result of both negative and positive effects of soil chemical and physical factors and weather conditions that cause different spatial and temporal distribution patterns of variables and crop yields. The above results highlight the potential for site-specific precision crop management to obtain more productive and sustainable crop production and show clearer agronomy interactions.

Author Contributions: A.N.: conceptualization, methodology, editing and manuscript writing, B.D.: statistical analysis and subsection writing; C.K.: statistical method and data curation, M.N.: subsection writing and review; A.J.K.: project administration and review. All authors have read and agreed to the published version of the manuscript.

Funding: This research was funded by Széchenyi István University.

Institutional Review Board Statement: Not applicable.

Informed Consent Statement: Not applicable.

Data Availability Statement: Not applicable.

Acknowledgments: The authors thank the "Thematic Excellence Program-National Challenges Subprogram-Complex Precision Crop Production Research at Széchenyi István University (TKP2020NKA-14)" project. BD was supported by MIS "Learning from Pairwise Comparisons" of the F.R.S.FNRS and by MTA Premium Postdoctoral Grant 2018.

Conflicts of Interest: The authors declare no conflict of interest.

\section{Appendix A}
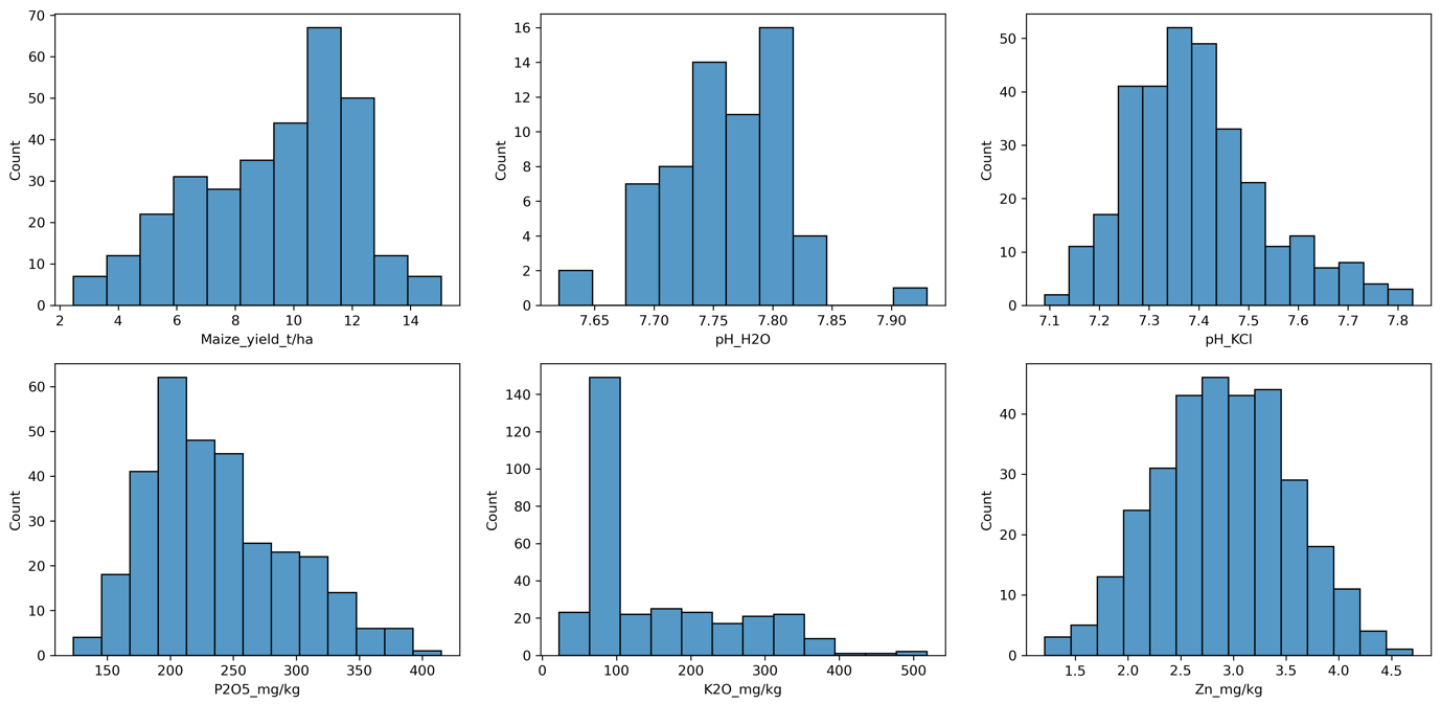

Figure A1. Cont. 

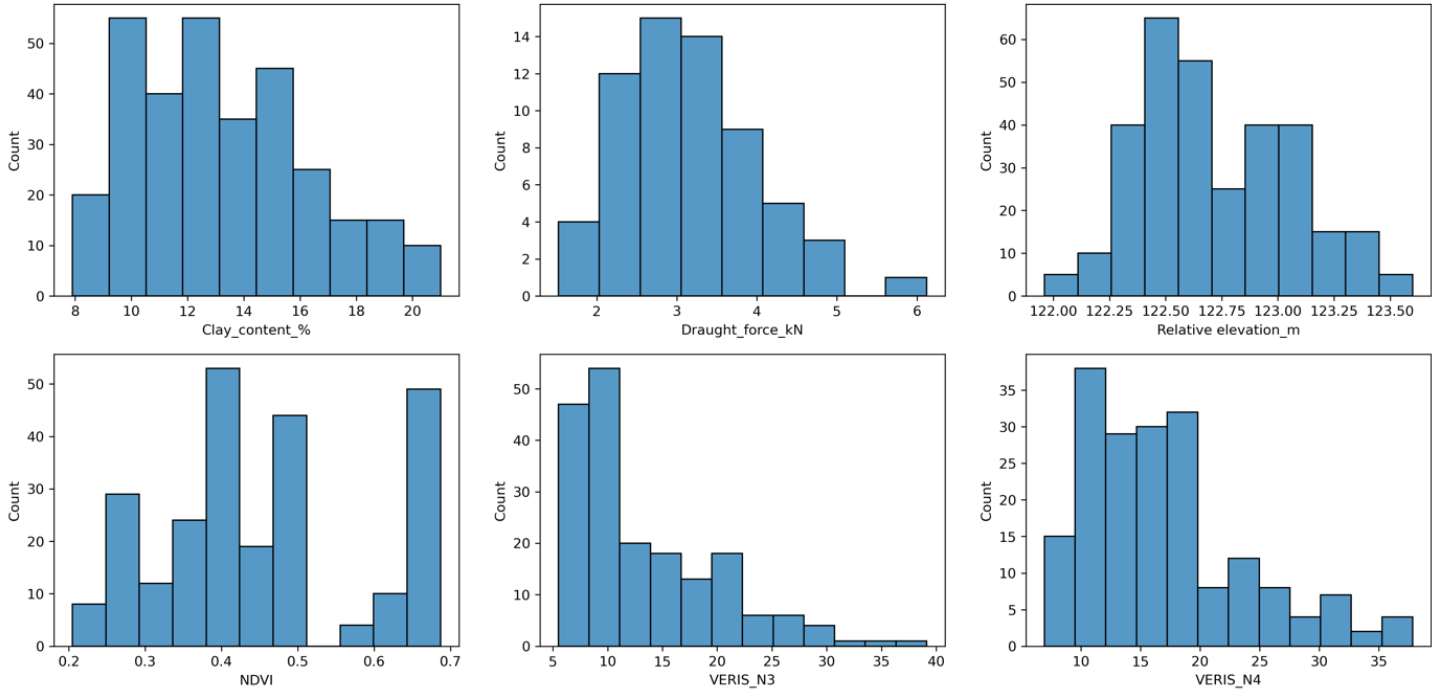

Figure A1. The histograms of variables.

\section{References}

1. Awe, G.O.; Reichert, J.M.; Timm, L.C.; Wendroth, O.O. Temporal processes of soil water status in a sugarcane field under residue management. Plant Soil 2014, 387, 395-411. [CrossRef]

2. Gajda, A.M.; Czyż, E.A.; Dexter, A.R. Effects of long-term use of different farming systems on some physical, chemical and microbiological parameters of soil quality. Int. Agrophys. 2016, 30, 165-172. [CrossRef]

3. Aranyos, J.T.; Tomócsik, A.; Makádi, M.; Mészáros, J.; Blaskó, L. Changes in physical properties of sandy soil after long-term compost treatment. Int. Agrophys. 2016, 30, 269-274. [CrossRef]

4. Nyéki, A.; Kerepesi, C.; Daróczy, B.; Benczúr, A.; Milics, G.; Kovács, A.J.; Neményi, M. Maize Yield Prediction Based on Artificial Intelligence Using Spatio-Temporal Data. In Proceedings of the Precision Agriculture'19, Wageningen, The Netherlands, 8 July 2019; Wageningen Academic Publishers: Wageningen, The Netherlands, 2019.

5. Basso, B.; Bertocco, M.; Sartori, L.; Martin, E.C. Analyzing the effects of climate variability on spatial pattern of yield in a maize-wheat-soybean rotation. Eur. J. Agron. 2007, 26, 82-91. [CrossRef]

6. Schepers, A.R.; Shanahan, J.F.; Liebig, M.A.; Schepers, J.S.; Johnson, S.H.; Luchiari, A. Appropriateness of management zones for characterizing spatial variability of soil properties and irrigated corn yields across years. Agron. J. 2004, 96, 195. [CrossRef]

7. Sánchez, T.; Ligarreto, M.; Leiva, F.R. Spatial variability of soil chemical properties and its effect on crop yields: A case study in maize (Zea mays L.) on the Bogota Plateau. Agron. Colomb. 2010, 29, 265-274.

8. Srinivasan, A. Handbook of Precision Agriculture: Principles and Applications; CRC Press: Boca Raton, FL, USA, 2006; ISBN 9781482277968.

9. Jug, I.; Brozović, B.; Đurđević, B.; Wilczewski, E.; Vukadinović, V.; Stipešević, B.; Jug, D. Response of crops to conservation tillage and nitrogen fertilization under different agroecological conditions. Agronomy 2021, 11, 2156. [CrossRef]

10. Jin, J.; Jiang, C. Spatial variability of soil nutrients and site-specific nutrient management in the China. Comput. Electron. Agric. 2002, 36, 165-172. [CrossRef]

11. Wendroth, O.; Jürschik, P.; Kersebaum, K.C.; Reuter, H.; van Kessel, C.; Nielsen, D.R. Identifying, understanding, and describing spatial processes in agricultural landscapes_four case studies. Soil Tillage Res. 2001, 58, 113-127. [CrossRef]

12. Mzuku, M.; Khosla, R.; Reich, R.; Inman, D.; Smith, F.; MacDonald, L. Spatial variability of measured soil properties across site-specific management zones. Soil Sci. Soc. Am. J. 2005, 69, 1572-1579. [CrossRef]

13. Diacono, M.; Castrignanò, A.; Troccoli, A.; De Benedetto, D.; Basso, B.; Rubino, P. Spatial and temporal variability of wheat grain yield and quality in a mediterranean environment: A multivariate geostatistical approach. Field Crops Res. 2012, 131, 49-62. [CrossRef]

14. Kool, D.; Tong, B.; Tian, Z.; Heitman, J.L.; Sauer, T.J.; Horton, R. Soil water retention and hydraulic conductivity dynamics following tillage. Soil Tillage Res. 2019, 193, 95-100. [CrossRef]

15. Nyéki, A.; Milics, G.; Kovács, A.J.; Neményi, M. Effects of soil compaction on cereal yield. Cereal Res. Commun. 2017, 45, 1-22. [CrossRef]

16. Soane, B.D.; van Ouwerkerk, C. Soil Compaction in Crop Production; Elsevier: Amsterdam, The Netherlands, 2013; ISBN 9780080934006.

17. Orrben, C.L.; Tharp, W.E. Soil Survey of Monroe County, Iowa; Bureau of Chemistry and Soils: Washington, DC, USA, 1935; ISBN 31210008546176. 
18. Franke, A.C.; Laberge, G.; Oyewole, B.D.; Schulz, S. A comparison between legume technologies and fallow, and their effects on maize and soil traits, in two distinct environments of the West African Savannah. Nutr. Cycl. Agroecosyst. 2008, 82, 117-135. [CrossRef]

19. Shukla, A.K.; Behera, S.K.; Lenka, N.K.; Tiwari, P.K.; Prakash, C.; Malik, R.S.; Sinha, N.K.; Singh, V.K.; Patra, A.K.; Chaudhary, S.K. Spatial variability of soil micronutrients in the intensively cultivated trans-gangetic plains of India. Soil Tillage Res. 2016, 163, 282-289. [CrossRef]

20. FAO World Reference Base for Soil Resources 2014. Available online: https:/ /www.fao.org/3/i3794en/I3794en.pdf (accessed on 26 January 2022).

21. Soil Classification. Available online: https://www.nrcs.usda.gov/wps/portal/nrcs/main/soils/survey/class/ (accessed on 5 January 2022).

22. Nyéki, A.; Kerepesi, C.; Daróczy, B.; Benczúr, A.; Milics, G.; Nagy, J.; Harsányi, E.; Kovács, A.J.; Neményi, M. Application of spatio-temporal data in site-specific maize yield prediction with machine learning methods. Precis. Agric. 2021, 22, 1397-1415. [CrossRef]

23. Neményi, M.; Mesterházi, P.Á.; Milics, G. An application of tillage force mapping as a cropping management tool. Biosyst. Eng. 2006, 94, 351-357. [CrossRef]

24. Szőllősi, I. A 3T SYSTEM Készülékkel Mért Penetrációs Ellenállás És Nedvességtartalom Összefüggése Vályog Fizikai Féleségú Talajon. Agrokémia És Talajt. 2003, 52, 263-274. [CrossRef]

25. Foroughifar, H.; Jafarzadeh, A.A.; Torabi, H.; Pakpour, A.; Miransari, M. Using geostatistics and geographic information system techniques to characterize spatial variability of soil properties, including micronutrients. Commun. Soil Sci. Plant Anal. 2013, 44, 1273-1281. [CrossRef]

26. Ayoubi, S.H.; Zamani, S.M.; Khormali, F. Spatial variability of some soil properties for site specific farming in northern Iran. Int. J. Plant Prod. 2007, 1, 225-236.

27. Miao, Y.; Mulla, D.J.; Robert, P.C. Identifying important factors influencing corn yield and grain quality variability using artificial neural networks. Precis. Agric. 2006, 7, 117-135. [CrossRef]

28. Vidana Gamage, D.N.; Biswas, A.; Strachan, I.B. Spatial variability of soil thermal properties and their relationships with physical properties at field scale. Soil Tillage Res. 2019, 193, 50-58. [CrossRef]

29. Usowicz, B.; Lipiec, J. Spatial variability of soil properties and cereal yield in a cultivated field on sandy soil. Soil Tillage Res. 2017, 174, 241-250. [CrossRef]

30. Rugira, P.; Ma, J.; Zheng, L.; Wu, C.; Liu, E. Application of DSSAT CERES-maize to identify the optimum irrigation management and sowing dates on improving maize yield in Northern China. Agronomy 2021, 11, 674. [CrossRef]

31. Scudiero, E.; Teatini, P.; Manoli, G.; Braga, F.; Skaggs, T.; Morari, F. Workflow to establish time-specific zones in precision agriculture by spatiotemporal integration of plant and soil sensing data. Agronomy 2018, 8, 253. [CrossRef] 